\title{
1 Co-occurrence, habitat use and activity pattern of carnivore species in a coastal area of
}

\section{Argentina}

4 Caruso N.C. ${ }^{\mathrm{a}, \mathrm{b},{ }^{*},}$, Luengos Vidal E.M. ${ }^{\mathrm{a}, \mathrm{b}}$, Manfredi M.C. ${ }^{\mathrm{a}}$, Araujo M.S. ${ }^{\mathrm{a}}$, Lucherini M., , 5 Casanave E.B., ${ }^{\mathrm{a}, \mathrm{b}}$

7 a Departamento de Biología, Bioquímica y Farmacia, Universidad Nacional del Sur (UNS), San 8 Juan 670, Bahía Blanca (8000), Buenos Aires, Argentina.

9 bInstituto de Ciencias Biológicas y Biomédicas del Sur, Universidad Nacional del Sur (UNS)-

10 CONICET, San Juan 671, Bahía Blanca (8000), Buenos Aires, Argentina.

11

12

$13{ }^{*}$ Corresponding author at: Departamento de Biología, Bioquímica y Farmacia, Universidad

14 Nacional del Sur (UNS), San Juan 670, Bahía Blanca (8000), Buenos Aires, Argentina. E-mail:

15 nccaruso@gmail.com (N. C. Caruso) 


\section{Abstract}

18 Land-sea interface is an ecotone where the intersection of marine and terrestrial ecosystems

19 create unique ecological conditions for terrestrial mobile species and freshwater-adapted

20 organisms to exploit marine-derived food resources. Mammalian carnivores play an important

21 role in almost any ecosystem where they live due to their top-down (or trophic cascade) effects

22 on prey species and primary producers, thus structuring ecosystems along varied food-web

23 pathways. We use camera trapping to study the patterns of coexistence, habitat use and activity

24 pattern of carnivores species in a coastal area in southern Buenos Aires province, Argentina. We

25 were able to detect five of the seven species of Mammalian carnivores being the Pampas fox

26 Lycalopex gymnocercus and Geoffroy's cat Leopardus geoffroyi the two most common.

27 Geoffroy's cat seems to use more intensively those areas close to the shoreline, while we found

28 little support of it for Pampas fox; which seems to use more inland areas. Congruently, we

29 found evidence of a lack of spatial and, to a lower extent, temporal avoidance between the two

30 most common carnivore species of our study area. Our findings support those previous studies

31 indicating that the coastal dunes have an important role in the conservation of the biodiversity of

32 Buenos Aires province. Wildlife conservation is compatible with carefully-designed ecotourism

33 and limited infrastructure development and this may be a unique chance for the areas of Buenos

34 Aires coast that have not been affected yet by poorly planned, conservation-unfriendly

35 urbanization.

36

37

38

39

40

41

42

43

44

45

46

47

48

49

50

51

52

53

54

55

56

57

58

59

Keywords: coexistence, daily activity, interspecific competition, maritime mammals, occupancy models, use of space 


\section{Introduction}

Land-sea interface is an ecotone where the intersection of marine and terrestrial ecosystems create unique ecological conditions. At this ecotone, terrestrial mobile species and freshwater-adapted organisms are able to get into near-shore marine and estuarine waters or inter-tidal and marginal habitats (e.g., supralittoral zone) to exploit marine-derived food resources (Carlton \& Hodder, 2003; Lillywhite, Sheehy III, \& Zaidan III, 2008). In coastal and island systems, allochthonous marine resources can greatly subsidize terrestrial food webs, especially in areas of low productivity. Indeed, marine inputs represent a resource subsidy that may contributes to higher population densities of terrestrial consumers than those supported by in situ terrestrial resources alone (Behrendorff, Leung, \& Allen, 2019; Brown et al., 2015; Rose \& Polis, 1998).

Mammalian carnivores play an important role in almost any ecosystem where they live due to their top-down (or trophic cascade) effects on prey species and primary producers (Glen \& Dickman, 2005; W. J. Ripple et al., 2014; Terborgh \& Estes, 2013). Moreover, large carnivores can potentially limit mesocarnivores species through intraguild competition, thus structuring ecosystems along varied food-web pathways (William J Ripple, Wirsing, Wilmers, \& Letnic, 2013; Suraci, Clinchy, Dill, Roberts, \& Zanette, 2016). Although a wide range of factors can affect carnivore populations, interspecific competition and resource partitioning have been proposed as one of the most important factors structuring carnivore communities (Di Bitetti, De Angelo, Di Blanco, \& Paviolo, 2010; May et al., 2008). Thus, the presence of a specie in a given environment is the results of a trade-off between the quality of the habitat and the interspecific competence that directly or indirectly limits the access to resources (Araujo \& Guisan, 2006; Soberón, 2007). Within this framework, MacArthur and Levins (1967) proposed that two competitive species can co exists only if their niche differ, at least partially, along one or more dimensions. Later, Schoener (1974) argued that niche segregation between two competitive species is multidimensional and that the spatial (habitat), the trophic, and the temporal are the most common niche dimensions on which two species segregate.

The aim of this study was to gain ecological information about the carnivore community in a coastal area that represents a relict of semi-natural grasslands in southern

Buenos Aires province, Argentina. Because the natural grasslands that previously covered almost the entire territory of the province have almost disappeared due to their transformation into croplands, these relicts have a high conservation value (Bilenca \& Miñarro, 2004). Thus, our primary objective was to understand the relevance of these coastal habitats for the conservation of the native community of carnivores. Additionally, we aimed to explore if the local carnivore community was randomly organized in terms of species' coexistence and interactions and if not, what are the main interspecific differences in habitat use and activity 
97 patterns. We hypothesized that carnivore community would be comparatively diverse and that

98 the species composing it would show relatively ample niche overlap between each other in

99 terms of habitat and activity pattern due to the greater availability of resources found in this

100 coastal area in relation to the habitats largely modified by anthropogenic activities typical of

101 more inland areas.

102

103

\section{Methods}

104

2.1. Study area

105

Fieldwork was carried out in the "Arroyo Los Gauchos Nature Reserve”, located in the southwestern most part of Buenos Aires province (Coronel Dorrego county, 3856'1.93"S, 6045'9.37"O; Figure 1). The “Arroyo Los Gauchos Nature Reserve” is a coastal protected area of $7.07 \mathrm{~km}^{2}$ forming part of the Pampas ecoregion. Its habitat is characterized by the presence of dunes, both non-vegetated and covered by psammophyte vegetation, and a general low topography with interdune depressions occupied by small wetland. The climate is temperate, the annual mean temperature is $14.1^{\circ} \mathrm{C}$, with a maximum in January and a minimum in July, and the annual mean precipitation is about 850 mm (Celsi \& Giussani, 2019; Monserrat, Celsi, \& Fontana, 2012).

Although the study area is formally protected by the provincial government since 2011,

116 access. Until now, human disturbance has had a low impact in comparison to the other coastal 117 areas of the province. Activities such as cattle farming, forestry (principally Eucaliptus ssp. and

118 Pinus ssp. plantations) and tourism -which are widespread elsewhere- are still limited and urban

119 development is low (Monserrat \& Celsi, 2009; Monserrat \& Codignotto, 2013). The area was 120 proposed as Valuable Grassland Area (Bilenca \& Miñarro, 2004) well before its establishment 121 as protected area due to its high biodiversity (more than 72 vascular plant species) and the 122 presence of endemic rare or endangered vertebrate species, including a rodent, Ctenomys 123 australis and a lizard, Liolaemus multimaculatus (Monserrat \& Celsi, 2009).

\subsection{Data collection}

126 We conducted camera trapping from January 2009 to March 2009 using a combination 127 of both film and digital camera traps. The photo-trapping stations $(\mathrm{N}=29)$ were located in places 128 where we had previously registered indirect evidence of carnivore activity or along trails. 129 Because the Geoffroy's cat is considered rare or nearly extinct in most of the anthropogenically 130 modified habitats of the territory of the province (Castillo, Luengos Vidal, Lucherini, \& 131 Casanave, 2008), we focused our efforts on this felid. Thus, to reduce the chances of missing

132 the presence of undetected Geoffroy's cat individuals, the stations were separated by an 133 approximate distance of $1 \mathrm{~km}$. This distance was selected based on the information on home 
range size and movements of Geoffroy's cats that were radiotracked in a previous study in the Pampas grassland (Manfredi, Soler, Lucherini, \& Casanave, 2006).

Odorous baits (Bobcat Urine and Bobcat Gland Lure) were used at all stations in order to increase detection probability of carnivores, which are frequently elusive species. At each station we deployed one camera that was running continuously and set up to work with the minimal delay between pictures available for each model. All cameras were operational 24 hours per day except in instances of malfunction or damage caused by cattle, climate or other factors. We checked cameras every 5 days to replace batteries, film or memory card and to ensure their proper functioning and we replaced the cameras when they failed to minimize the amount of missing data. Sampling effort was calculated as the sum of the effective sampling days (omitting those days in which the cameras did not work) along the total number of stations (Di Bitetti, Paviolo, \& De Angelo, 2006).

The habitat surrounding camera stations was in situ evaluated within a radius of $20 \mathrm{~m}$ to visually estimate the proportion of each habitat type. Seven habitat types were identified as the most characteristics in the study area: "BG", bare ground, mostly non-vegetated dunes or any other portion of land without vegetation cover; "LG”, low grassland, grasses (Poaceae) less than $30 \mathrm{~cm}$ tall; "TG", medium-tall grassland, areas covered by grassy vegetation (Poaceae) taller than $30 \mathrm{~cm}$; “J”, areas covered by Juncus spp.; “C”, areas covered by Cortaderia spp.; "H”, areas covered by Hyalis argentea; "S", shrubland, mostly dominated by Lycium chilensis, Baccharis divaricata and Discaria americana. Additional we measured “ $\mathrm{D}$ ”, the linear distance (m) from each camera station to the shoreline. For the following analysis, variables representing proportions where arcsin transformed, while the distance was log-transformed.

\subsection{Statistical analysis}

We first explored co-occurrence patterns among species across the study area using the probabilistic species co-occurrence models developed by Veech (2013). These models use the hypergeometric distribution to calculate the probability that two species spatially co-occur either less or more often than expected based on their mean incidence probabilities (Griffith, Veech, \& Marsh, 2016). Using the observed co-occurrence frequencies and a specified alpha level (in this case, $\alpha=0.05$ ), species co-occurrences were classified as significantly positive or negative, or occurring at random.

Aside from the null model-based analyses, we explored through a multivariate analysis the potential association between the carnivore community composition and the variation in the site variables. First, we performed a non-metric multidimensional scaling (NMDS) on a similarity matrix constructed with Hellinger-transformed abundance data using the Bray-Curtis dissimilarity measure (Legendre \& Legendre, 2012). The Hellinger transformation divides each cell by the total abundance at a site and then takes the square root (therefore reducing the effect 
171 of extremely abundant species), and has previously been shown to have desirable properties in

172 the context of ordination (Legendre \& Gallagher, 2001). Carnivore abundance was estimated

173 through the relative abundance index (hereafter RAI; Carbone et al., 2001) by calculating the

174 number of independent photographs divided by the total number of trap nights. This index was

175 also used as an indicator of the intensity of habitat use by each species at each site. We consider

176 as independent event those photographs taken with a delay greater than 45 min between each

177 other. The assemblage environment relationships were examined by a post hoc fitting of

178 environmental vectors onto the ordination space (Borcard, Gillet, \& Legendre, 2018; Kindt \&

179 Coe, 2005). The result is a group of vectors with endpoint showing the direction of the

180 environmental gradient, and a length that is proportional to the correlation between the

181 environmental variable and the ordering of the NMDS. Beside the stress value, we checked the

182 quality of the NMDS through Shepard plot and the significance of fitted vectors was assessed

183 using a permutations test ( $\mathrm{n}=999)$.

184 Additionally, and to take into account heterogeneous detection probabilities, we fit

185 single-species single-season occupancy models to our data (MacKenzie et al., 2002, 2017). To

186 avoid fitting a large number of models relative to the size of our dataset, we used the most

187 influential variables resulted from the NMDS analysis as covariates into our occupancy models.

188 Additionally, we used Hellinger-transformed RAI as covariable to evaluate potential effect of

189 the capture rate of a given species on the probability of occupancy of other species. We carried

190 out a model selection procedure and used the Akaike Information Criterion corrected for small

191 sample sizes (AICc) to select supported models from sets of candidate models (Birochio, 2008;

192 Burnham \& Anderson, 2002). We considered being most supported those models with the

193 lowest AICc score and the smallest number of parameters within 2 AICc units of the lowest

194 AICc score. We conducted the following modeling procedure for each species: we first modeled

195 the probability of detection by keeping the occupancy parameter constant and allowing

196 detection to vary as a function of the covariates previously mentioned. For model selection, we

197 considered all subsets and used AICc to identify the most supported model. We retained the

198 most supported model to serve as the detection parameter for all subsequent models for that

199 species. After that, to model the probability of occupancy, we built an initial additive global

200 model consisting of the retained detection parameter and linear terms for each site-level

201 covariate, we evaluated all subsets, and we considered the most supported model as our top

202 model. To assess fit of each top model, we used a MacKenzie-Bailey goodness-of-fit test with

203 parametric bootstrapping employing 1,000 simulations to approximate the distribution of the

204 test statistic (MacKenzie \& Bailey, 2004).

205 To study the daily activity patterns of carnivore species, we used the information on

206 record time saved on each camera trap photograph to construct and visually evaluate circular

207 plots representing the distribution of records along the 24-h cycle for each species and then 
208 tested for non-uniformity using the Rayleigh test (Jammalamadaka \& SenGupta, 2001).

209 Additionally, to evaluate the level of temporal overlap between species we fitted a Kernel-

210 density estimation that describes the temporal activity of each species and then calculated a

211 coefficient of overlap in pairwise comparisons. As suggested by Ridout and Linkie (2009), we

212 used the $\Delta 1$ estimator for those cases where the smallest number of photographic records was

213 less than 50. This coefficient estimates the level of overlap between two activity distributions,

214 and its value range from 0 for no overlap, to 1 for identical distributions. Given the small

215 amount of records obtained for G. cuja and C. chinga, we only studied the temporal overlap

216 between L. geoffroyi and L. gymnocercus. We obtained confidence intervals for each estimator

217 using a bootstrap procedure (Linkie \& Ridout, 2011).

218 All statistical analysis were performed in R (version 3.6.1) (R Development Core Team,

219 2013), using the package "cooccur” (Griffith et al., 2016), "unmarked” (Fiske \& Chandler,

220 2011), “MuMIn” (Bartoń, 2013) and “overlap” (Meredith \& Ridout, 2017).

\section{Results}

Total sampling effort was 1414 camera trap days and the mean effort per camera/sampling station was 48.75 days (range $=46-51$ days). We obtained 83 independent records of carnivore species. The carnivore community of this area was formed by five species: the Pampas fox Lycalopex gymnocercus, Geoffroy's cat Leopardus geoffroyi, Molina's hognosed skunk Conepatus chinga, puma Puma concolor, and Lesser grison Galictis cuja.

228 Although the jaguarundi Puma yagouaroundi and Pampas cat Leopardus colocolo are presumed to occur in this region, these felids were not detected in our survey. The following noncarnivore mammal species were also found in the "Arroyo Los Gauchos Nature Reserve”: the

231 European red deer Cervus elaphus, European hare Lepus europaeus, wild boar Sus scrofa (three

232 introduced species), big hairy armadillo Chaetophractus villosus, and several small rodents. It is 233 also worth mentioning the presence of the Greater Rhea Rhea americana, a large bird that is 234 listed as Vulnerable in Argentina (Navarro \& Martella, 2011). Lycalopex gymnocercus and L. 235 geoffroyi were the species with greatest RAI (3.68 and 1.49 independent events $\times 100$ day $^{-1}$, 236 respectively), followed by C. chinga (0.28), P. concolor (0.21), and G. cuja (0.21) (Table 1$)$.

237 Leopardus geoffroyi and C. chinga co-occurred at 3 sites, an amount significantly 238 higher than the expected 1 station $(\mathrm{Pgr}=0.033$, Table 2). Similarly, L. geoffroyi and $L$. 239 gymnocercus co-occurred at 8 sites while they were expected to co-occur at 5.9 sites; however, 240 in this case, the p-value was only marginally significative ( $\mathrm{Pgr}=0.096$, Table 2 ). The rest of the 241 species paired combinations did not show any differences with a theoretical random pattern of 242 co-occurrence.

243 The NMDS analysis showed a stress value of 0.028 and the Shepard plot did not show 244 discrepancies between the original dissimilarities and the multidimentional scaling solution $\left(\mathrm{R}^{2}\right.$ 

$=0.99)$. Axes were significantly related to the distance to shoreline $(\mathrm{p}<0.05)$ and marginally so to the proportion of tall grassland ( $\mathrm{p}=0.096$ ) (Figure 2). Leopardus geoffroyi appeared to be the species more strongly associated to sites near the shoreline and with higher proportion of tall grassland and, to a lesser extent, Cortaderia spp.; whereas L. gymnocercus tended to use the most inland sites, relatively farther from the shoreline and with higher proportion of $H$. argentea and low grassland, and a smaller proportion of tall grassland. Puma concolor appeared to be strongly associated to sites with higher proportion of Juncus spp. and tall grassland, a smaller proportion of Cortaderia spp., and relatively far from the coast. Conepatus chinga habitat use was related to sites with small proportion of Juncus spp. and high percentage of Cortaderia spp. and, to a lesser extent, bare ground. Finally, G. cuja showed an association to sites not close to the shoreline, with higher proportion of Juncus spp. and tall grassland, and less Cortaderia spp.

The top occupancy models for L. gymnocercus, C. chinga, G. cuja, and P. concolor exhibited evidence of model fit ( $\mathrm{P}>0.05)$, whereas lack of fit $(\mathrm{p} \approx 0.05)$ and overdispersion $(\hat{c}>$ 2) was found in the top model for L. geoffroyi (Table 4). The top models for both Pampas fox and Geoffroy's cat included a negative logistic relationship with the proportions of Juncus sp. and of tall grassland for the occupancy parameter (Table 4). The detection probability for Pampas foxes was negatively related to the proportion of Juncus $s p$. and positively to the distance to the shoreline, while it was positively related to Juncus sp. for Geoffroy's cat. A negative effect of the distance from the shoreline on the probability of occupancy of this felid was found in three of the four models included in the set with $\Delta$ AICc $<2$. Although it was not the case for the top model, the occupancy probability of Geoffroy's cat showed a positive relationship with the occupancy probability of Pampas fox, and vice versa. Top models for both C. chinga and G. cuja did not support any variable for the detection parameter, but showed a logistic positive relationship with the capture rate of Pampas fox (for the case of C. chinga) and a positive relationship with the proportion of Juncus sp. (for the case of G. cuja). Puma concolor was the only species with a single model in the set of models with AICc $<2$ that showed a negative relationship with distance to the shoreline for the detection parameter and a positive relationship with the same variable for the occupancy parameter.

Carnivores were mostly nocturnal, except for G. cuja, which was only captured during daytime (Figure 4). All records of the $P$. concolor and almost all those of $C$. chinga were obtained at night. The Pampas fox seemed to have a bimodal pattern with activity concentrated between 22:00 - 23:00 and 3:00 - 4:00. The highest rate of increase in activity was at dusk (approximately at 21:00) and only few pictures were recorded during daytime (21.6\% of the independent events). Most of the events of the Geoffroy's cat were obtained during nighttime, with a concentration around midnight (0:00 - 1:00). There were no records during daytime and 
281 a few in crepuscular periods. Pampas fox and Geoffroy's cat showed a relatively similar activity

282 patterns $\left(\Delta_{1}=0.786 ; \mathrm{CI}=0.624-0.901\right)$.

\section{Discussion}

With a relatively limited surveying effort we were able to detect five of the seven species of Mammalian carnivores that may potentially occur in the coastal area of the southern part of Buenos Aires province. Although we were not able to record the presence of the Pampas cat and the jaguaroundi, we cannot exclude the possibility that they simply went undetected. Based on the presence of Pampas cats in the sandy dune areas found less than $200 \mathrm{~km}$ away in the Espinal ecoregion of Buenos Aires province (Caruso, Manfredi, Vidal, Casanave, \&

291 Lucherini, 2012) and other records in proximity of the city of Bahia Blanca (located aprox. 100

$292 \mathrm{~km}$ away), this possibility appears more likely for this felid than the jaguaroundi. There are no 293 recent records of the latter in the region and its population densities in the southernmost part of

294 Buenos Aires province appear to be very low (Luengos Vidal, Guerisoli, Caruso, \& Lucherini, 295 2017). A comparison with the previous information available suggests that in neighboring 296 Pampas areas, which have been more intensively affected by anthropogenic modifications, some 297 of the species we recorded are rare, such as the Geoffroy's cat (Castillo et al., 2008), or in a 298 process of recolonization, such as the puma (Chimento \& De Lucca, 2014). Furthermore, the capture rates (RAI) found in our study area indicates that Geoffroy's cats are similarly abundant and pumas are even more common compared to a protected area (Reserva Natural de Objetivo Definido Laguna de Chasicó) with relatively preserved woodland typical of the Espinal ecoregion of Buenos Aires province (Benzaquín, 2008; Caruso et al., 2012).

Both the RAI values and the naïve occupancy (i.e., the proportion of sampling site where a species is recorded) showed that the Pampas fox is the most common carnivore species in the coastal area of the southern part of Buenos Aires province, followed by the Geoffroy's cat. The numeric dominance of Pampas fox is not surprising, because this canid is a very adaptable carnivores, capable of opportunistically feed on a variety of prey (e.g., Bossi, Migliorini, Santos, \& Kasper, 2019; Castillo, Birochio, Lucherini, \& Casanave, 2011; Farias \& Kittlein, 2008) and still relatively common in the agroecosystems of the Pampas. Conversely, the relatively high frequency of records and occupancy of the Geoffroy's cat in our study area,

311 especially when compared to those of C. chinga and G. cuja, was unexpected, based on the

312 available information on the present-day Pampas landscapes. Although caution is required when

313 comparing data that do not account for differences in detection probability, the information 314 recorded previously in the Argentine Pampas indicate that C. chinga is the second most 315 abundant carnivore both in natural mountain grasslands and croplands (Luengos Vidal, 2009). 316 C. chinga was also found to be very abundant in the Brazilian Pampas, where this Mephitid 317 could even become the most common carnivore in intensive agriculture areas and ranchlands, 
318 while the Geoffroy's cat was much rarer (Kasper et al., 2012). Thus, our findings suggest that

319 the "Arroyo Los Gauchos Nature Reserve" can be conserving habitats where the carnivore

320 community is able to maintain relatively high densities of species that are comparatively more

321 sensitive to human interference such as the Geoffroy’s cat and the puma.

322 Because Pampas foxes readily eats carrion and have been reported to prey on several

323 animals associated to saline water, such as crabs, crustaceans, and even fish (García and

324 Kittlein, 2005; Lucherini and Luengos Vidal, 2008; Bossi et al., 2019), these canids could be

325 expected to use the areas close to the shoreline more intensively than other carnivores. We

326 found little support for this hypothesis. Only one of the top four models included a negative

327 relationship between the distance from the shoreline and the Pampas fox occupancy.

328 Additionally, the NMDS analysis showed that L. gymnocercus tended to use more intensively

329 sites at greater distances from the ocean. However, the finding that the probability of detecting

330 this canid also increases with increasing distance from the shoreline may indicate that the

331 NMDS results are affected by this greater detection. Also contrary to our expectations, the

332 negative effect of the distance from the shoreline on the probability of occupation appeared to

333 be stronger for the Geoffroy's cat, which is in accordance also with the results of the NMDS

334 analysis. There are several possible explanations for these findings, but we argue that the spatial

335 distribution of resource availability is a mayor candidate and a factor that should be investigated

336 for a better understanding of the dynamics carnivore habitat use in this ecosystem.

337 In agreement with our initial hypothesis - and congruently with the results of the

338 occupancy analysis -, we found evidence of a lack of spatial and, to a lower extent, temporal

339 avoidance between the two most common carnivore species of our study area. These results are

340 similar to those found by a previous study that specifically addressed the mechanisms of

341 coexistence between $L$. geoffroyi and the culpeo Lycalopex culpaeus, a fox slightly larger than

342 the Pampas fox (Gantchoff \& Belant, 2016). These authors found high spatio-temporal overlap

343 between these two carnivores and concluded that diet segregation was the most likely

344 mechanism favoring their coexistence in the Andean forest of Patagonia (Gantchoff \& Belant,

345 2016). Based on the available information on the trophic niche of the Geoffroy's cat and the

346 Pampas fox, in general and in areas where they co-occur (Kasper, Peters, Christoff, \& de

347 Freitas, 2016), we argue that dietary segregation, coupled and possibly also made possible, by

348 the diversity and abundance of food resources found in our study site, may be the major factor

349 facilitating the coexistence of these two carnivores in the coastal areas of Buenos Aires

350 province.

\section{5. Conclusions}

353 Our findings support those from Bilenca y Miñarro (Bilenca \& Miñarro, 2004) and

354 (Monserrat \& Celsi, 2009; Monserrat et al., 2012) indicating that the coastal dunes have an 
important role in the conservation of the biodiversity of Buenos Aires province. They protect not only endemic species with very limited distributions but also offer refuge to species that were probably more common in the natural ecosystems typical of the Pampas grassland before they were heavily transformed by anthropogenic activities. This conclusion is supported by the relatively diversified and abundant guild of vertebrates, especially carnivores, that we found. It is clear that the vertebrate community of the coastal areas of Buenos Aires cannot be considered pristine, not only because they are typically used as grazing areas for extensive livestock activities but also because of the presence of several introduced species. However, livestock has not made irreversible damages yet and the presence of exotic prey may reduce the potential conflicts between carnivores (namely, P. concolor and L. gymnocercus) and ranchers over predation on livestock, which are intense in Buenos Aires province (De Lucca, 2010; Guerisoli et al., 2017). Although more information is certainly required, we conclude that the coastal areas of the southernmost portion of Buenos Aires deserve protection. This does not necessarily imply a complete halt to tourism development, the activity that currently seems the strongest and most promising economic activity for these coasts. Wildlife conservation is compatible with carefully-designed ecotourism and limited infrastructure development and this may be a unique chance for the areas of Buenos Aires coast that have not been affected yet by poorly planned, conservation-unfriendly urbanization.

\section{Acknowledgment}

This work was financially supported by Secretaría General de Ciencia y Técnica - Universidad Nacional del Sur (PGI 24/B152, 24/B198 and 24/B243) to EBC and Université de Sherbrooke (Maîtrise en Biologie - Écologie Internationale). M.C.M. and M.S.A. were founded by a postdoctoral and a doctoral scholarship, respectively, from the Consejo Nacional de Investigaciones Científicas y Técnicas (CONICET). We would like to express our special gratitude to the ranch owners surrounding the study area who kindly provided us with logistics support in the field. We also thank to V. Robichaud, P. Costilla and G. Zapperi who collaborated with fieldwork, data entry and statistical analysis.

\section{References}

Araujo, M. B., \& Guisan, A. (2006). Five (or so) challenges for species distribution modelling. Journal of Biogeography, 33(10), 1677-1688.

Bartoń, K. (2013). MuMIn: multi-model inference, R package version 1.9.13.

Behrendorff, L., Leung, L. K.-P., \& Allen, B. L. (2019). Utilisation of stranded marine fauna washed ashore on K'gari (Fraser Island), Australia, by dingoes. Australian Journal of Zoology, 66(2), 128-138. 
Benzaquín, M. (2008). Área de acción del gato montés (Leopardus geoffroyi) en una zona de la provincia fitogeográfica del Espinal. Chasicó, Pdo. de Villarino. Buenos Aires. B. Sc. thesis, Universidad Nacional del Litoral, Santa Fé.

Bilenca, D., \& Miñarro, F. (2004). Identificacion de Areas Valiosas de Pastizal en las pampas y campos de Argentina, Uruguay y sur de Brasil (AVPs). Fundación Vida Silvestre.

Birochio, D. (2008). Ecología trófica de Lycalopex gymnocercus en la región pampeana: un acercamiento inferencial al uso de los recursos. Universidad Nacional del Sur.

Borcard, D., Gillet, F., \& Legendre, P. (2018). Numerical ecology with R. Springer.

Bossi, M. A. S., Migliorini, R. P., Santos, T. G., \& Kasper, C. B. (2019). Comparative trophic ecology of two sympatric canids in the Brazilian Pampa. Journal of Zoology, 307(3), 215222.

Brown, M. B., Schlacher, T. A., Schoeman, D. S., Weston, M. l A., Huijbers, C. M., Olds, A. D., \& Connolly, R. M. (2015). Invasive carnivores alter ecological function and enhance complementarity in scavenger assemblages on ocean beaches. Ecology, 96(10), 27152725.

Burnham, K. P., \& Anderson, D. R. (2002). Model selection and multimodel inference: a practical information-theoretic approach. Springer, New York.

Carbone, C., Christie, S., Conforti, K., Coulson, T., Franklin, N., Ginsberg, J. R., ... Shahruddin, W. N. W. (2001). The use of photographic rates to estimate densities of tigers and other cryptic mammals. Animal Conservation, 4, 75-79.

Carlton, J. T., \& Hodder, J. (2003). Maritime mammals: terrestrial mammals as consumers in marine intertidal communities. Marine Ecology Progress Series, 256, 271-286.

Caruso, N., Manfredi, C., Vidal, E. M. L., Casanave, E. B., \& Lucherini, M. (2012). First density estimation of two sympatric small sats, Leopardus colocolo and Leopardus geoffroyi, in a shrubland area of central Argentina. Annales Zoologici Fennici, 49(3), 181191.

Castillo, D. F., Birochio, D. E., Lucherini, M., \& Casanave, E. B. (2011). Diet of adults and cubs of Lycalopex gymnocercus in Pampas grassland: a validation of the Optimal Foraging Theory? Annales Zoologici Fennici, 80(3), 251-256.

Castillo, D. F., Luengos Vidal, E. M., Lucherini, M., \& Casanave, E. B. (2008). First Report on the Geoffroy's cat in a highly modified rural area of the Argentine pampas. Cat News, 49, 27-28.

Celsi, C. E., \& Giussani, L. M. (2019). Geographical distribution and habitat characterization of Poa schizantha (Poaceae), a narrow endemic of the coastal sand dunes of the southern Pampas, Argentina. Botanical Journal of the Linnean Society, 192(1), 296-313.

Chimento, N. R., \& De Lucca, E. R. (2014). El Puma (Puma concolor) recoloniza el centro y este del ecosistema de las Pampas. Historia Natural, 4(2), 13-51.

De Lucca, E. R. (2010). Presencia del puma (Puma concolor) y conflicto con el hombre en las pampas argentinas. Nótulas Faunísticas (Segunda Serie), 48, 1-17. 
Di Bitetti, M. S., De Angelo, C. D., Di Blanco, Y. E., \& Paviolo, A. (2010). Niche partitioning and species coexistence in a Neotropical felid assemblage. Acta Oecologica, 36(4), 403412.

Di Bitetti, M. S., Paviolo, A., \& De Angelo, C. (2006). Density, habitat use and activity patterns of ocelots (Leopardus pardalis) in the Atlantic Forest of Misiones, Argentina. Journal of Zoology, 270(1), 153-163.

Farias, A. A., \& Kittlein, M. J. (2008). Small-scale spatial variability in the diet of pampas foxes (Pseudalopex gymnocercus) and human-induced changes in prey base. Ecological Research, 23(3), 543-550.

Fiske, I., \& Chandler, R. (2011). unmarked: An R package for fitting hierarchical models of wildlife occurrence and abundance. Journal of Statistical Software, 43(10), 1-23.

Gantchoff, M. G., \& Belant, J. L. (2016). Patterns of coexistence between two mesocarnivores in northern $\mathrm{P}$ atagonia in the presence of invasive hares and anthropogenic disturbance. Austral Ecology, 41(1), 97-105.

Glen, A. S., \& Dickman, C. R. (2005). Complex interactions among mammalian carnivores in Australia, and their implications for wildlife management. Biological Reviews, 80(3), 387401.

Griffith, D. M., Veech, J. A., \& Marsh, C. J. (2016). Cooccur: probabilistic species cooccurrence analysis in R. Journal of Statistical Software, 69(2), 1-17.

Guerisoli, M. de las M., Luengos Vidal, E. M., Franchini, M., Caruso, N., Casanave, E. B., \& Lucherini, M. (2017). Characterization of puma-livestock conflicts in rangelands of central Argentina. Royal Society Open Science, 4(12), 170852.

Jammalamadaka, S. R., \& SenGupta, A. (2001). Topics in Circular Statistics. In Statistics (Vol. 6). https://doi.org/10.1111/j.1442-2050.2010.01169.x

Kasper, C. B., Peters, F. B., Christoff, A. U., \& de Freitas, T. R. O. (2016). Trophic relationships of sympatric small carnivores in fragmented landscapes of southern Brazil: niche overlap and potential for competition. Mammalia, 80(2), 143-152.

Kindt, R., \& Coe, R. (2005). Tree diversity analysis: a manual and software for common statistical methods for ecological and biodiversity studies. World Agroforestry Centre.

Legendre, P., \& Gallagher, E. D. (2001). Ecologically meaningful transformations for ordination of species data. Oecologia, 129(2), 271-280.

Legendre, P., \& Legendre, L. F. J. (2012). Numerical ecology (Vol. 20). Elsevier.

Lillywhite, H. B., Sheehy III, C. M., \& Zaidan III, F. (2008). Pitviper scavenging at the intertidal zone: an evolutionary scenario for invasion of the sea. BioScience, 58(10), 947955.

Linkie, M., \& Ridout, M. S. (2011). Assessing tiger-prey interactions in Sumatran rainforests. Journal of Zoology, 284(3), 224-229.

Luengos Vidal, E. M. (2009). Organización espacial de Pseudalopex gymnocercus en los pastizales pampeanos. PhD. thesis, Universidad Nacional del Sur. 
Luengos Vidal, E. M., Guerisoli, M., Caruso, N., \& Lucherini, M. (2017). Updating the distribution and population status of jaguarundi, puma yagouaroundi (É. Geoffroy, 1803) (Mammalia: Carnivora: Felidae), in the southernmost part of its distribution range. Check List, 13(4).

MacArthur, R., \& Levins, R. (1967). The Limiting Similarity, Convergence, and Divergence of Coexisting Species. The American Naturalist, 101(921), 377-385.

MacKenzie, D. I., \& Bailey, L. L. (2004). Assessing the fit of site-occupancy models. Journal of Agricultural, Biological, and Environmental Statistics, 9(3), 300-318.

MacKenzie, D. I., Nichols, J. D., Lachman, G. B., Droege, S., Royle, J. A., \& Langtimm, C. A. (2002). Estimating site occupancy rates when detection probabilities are less than one. Ecology, 83(8), 2248-2255.

MacKenzie, D. I., Nichols, J. D., Royle, J. A., Pollock, K. H., Bailey, L., \& Hines, J. E. (2017). Occupancy estimation and modeling: inferring patterns and dynamics of species occurrence. Elsevier.

Manfredi, C., Soler, L., Lucherini, M., \& Casanave, E. B. (2006). Home range and habitat use by Geoffroy's cat (Oncifelis geoffroyi) in a wet grassland in Argentina. Journal of Zoology, 268(4), 381-387.

May, R., Van Dijk, J., Wabakken, P., Swenson, J. E., Linnell, J. D. C., Zimmermann, B., ... Landa, A. (2008). Habitat differentiation within the large carnivore community of Norway's multiple use landscapes. Journal of Applied Ecology, 45(5), 1382-1391.

Meredith, M., \& Ridout, M. (2017). Overview of the Overlap Package. Retrieved from https://cran.r-project.org/web/packages/overlap/vignettes/overlap.pdf

Monserrat, A. L., \& Celsi, C. E. (2009). Análisis regional de la costa pampeana austral en el marco del sistema de áreas protegidas y caracterización de un área clave como reserva, en el partido de coronel dorrego. Bioscriba, 2(1), 1-23.

Monserrat, A. L., Celsi, C. E., \& Fontana, S. L. (2012). Coastal Dune Vegetation of the Southern Pampas (Buenos Aires, Argentina) and Its Value for Conservation. Journal of Coastal Research, 279, 23-35.

Monserrat, A. L., \& Codignotto, J. O. (2013). Geodiversidad pampeana: Geomorfología y conservación de los paisajes de dunas costeras. Comunicacoes Geologicas, 100(1), 21-32.

Navarro, J. L., \& Martella, M. B. (2011). Ratite conservation: Linking captive-release and welfare. In The welfare of farmed ratites (pp. 237-258). Springer.

R Development Core Team. (2013). R: A Language and Environment for Statistical Computing. Vienna, Austria: R Foundation for Statistical Computing. www.R-project.org.

Ridout, M. S., \& Linkie, M. (2009). Estimating overlap of daily activity patterns from camera trap data. Journal of Agricultural, Biological, and Environmental Statistics, 14(3), 322337. 
bioRxiv preprint doi: https://doi.org/10.1101/2020.03 .04.976415. this version posted March 5,2020 . The copyright holder for this preprint

(which was not certified by peer review) is the author/funder, who has granted bioRxiv a license to display the preprint in perpetuity. It is made available under aCC-BY-NC-ND 4.0 International license.

507 Ripple, W. J., Estes, J. A., Beschta, R. L., Wilmers, C. C., Ritchie, E. G., Hebblewhite, M., ... 508 Wirsing, A. J. (2014). Status and Ecological Effects of the World's Largest Carnivores. $509 \quad$ Science, 343(6167), 1241484-1241484.

510 Ripple, William J, Wirsing, A. J., Wilmers, C. C., \& Letnic, M. (2013). Widespread 511 mesopredator effects after wolf extirpation. Biological Conservation, 160, 70-79.

512 Rose, M. D., \& Polis, G. A. (1998). The distribution and abundance of coyotes: the effects of 513 allochthonous food subsidies from the sea. Ecology, 79(3), 998-1007.

514 Schoener, T. W. (1974). Resource partitioning in ecological communities. Science, 185(4145), 515 27-39.

516 Soberón, J. (2007). Grinnellian and Eltonian niches and geographic distributions of species. $517 \quad$ Ecology Letters, 10(12), 1115-1123.

518 Suraci, J. P., Clinchy, M., Dill, L. M., Roberts, D., \& Zanette, L. Y. (2016). Fear of large $519 \quad$ carnivores causes a trophic cascade. Nature Communications, 7, 10698.

520 Terborgh, J., \& Estes, J. A. (2013). Trophic cascades: predators, prey, and the changing 521 dynamics of nature. Island Press.

522 Veech, J. A. (2013). A probabilistic model for analysing species co occurrence. Global 523 Ecology and Biogeography, 22(2), 252-260. 
bioRxiv preprint doi: https://doi org/10.1101/2020.03.04.976415: this version posted March 5.2020 . The copyright holder for this preprint (which was not certified by peer review) is the author/funder, who has granted bioRxiv a license to display the preprint in perpetuity. It is made available under aCC-BY-NC-ND 4.0 International license.

525 Table 1. Summary of the number and percentage of independent photographic events, the 526 capture rate (RAI) for the carnivore species found in a coastal area of Buenos Aires province 527 (Argentina), and the number and percentage of sites were each one was detected.

528

\begin{tabular}{lccc}
\hline Species & $\begin{array}{c}\mathbf{N}^{\circ} \text { photographic } \\
\text { events (\%) }\end{array}$ & $\begin{array}{c}\text { RAI (No } \mathbf{~ p h o t o g r a p h i c ~} \\
\left.\text { events } \times \mathbf{~ 1 0 0 ~} \text { day }^{-1}\right)\end{array}$ & $\begin{array}{c}\mathbf{N}^{\circ} \text { of sites with } \\
\text { positive detection (\%) }\end{array}$ \\
\hline L. gymnocercus & $52(62)$ & 3.68 & $17(58.6)$ \\
\hline L geoffroyi & $21(25)$ & 1.49 & $10(34.5)$ \\
\hline C. chinga & $4(5)$ & 0.28 & $3(10.3)$ \\
\hline P. concolor & $3(4)$ & 0.21 & $2(6.9)$ \\
\hline G. cuja & $3(4)$ & 0.21 & $3(10.3)$ \\
\hline
\end{tabular}

Table 2. Pairwise comparison of the probability of spatial co-occurrence for all five carnivore species combinations in a coastal area of Buenos Aires province, Argentina. Values of $\mathrm{P}_{\mathrm{lt}}<0.05$ indicate spatial segregation while values of $\mathrm{P}_{\mathrm{gt}}<0.05$ indicate a positive association. Sites $\mathrm{A}$ and respectively.

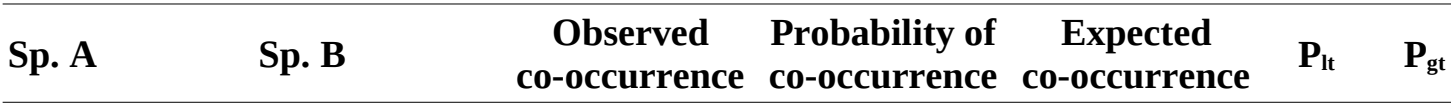

\begin{tabular}{lllllll}
\hline L. geoffroyi & L. gymnocercus & 8 & 0.202 & 5.900 & 0.984 & $\mathbf{0 . 0 9 6}$ \\
\hline L. geoffroyi & C. chinga & 3 & 0.036 & 1.000 & 1.000 & $\mathbf{0 . 0 3 3}$ \\
\hline L. geoffroyi & P. concolor & 1 & 0.024 & 0.700 & 0.889 & 0.579 \\
\hline L. geoffroyi & G. cuja & 0 & 0.036 & 1.000 & 0.265 & 1.000 \\
\hline L. gymnocercus & C. chinga & 3 & 0.061 & 1.800 & 1.000 & 0.186 \\
\hline L. gymnocercus & P. concolor & 1 & 0.040 & 1.200 & 0.665 & 0.837 \\
\hline L. gymnocercus G. cuja & 3 & 0.061 & 1.800 & 1.000 & 0.186 \\
\hline C. chinga & P. concolor & 0 & 0.007 & 0.200 & 0.800 & 1.000 \\
\hline C. chinga & G. cuja & 0 & 0.011 & 0.300 & 0.712 & 1.000 \\
\hline P. concolor & G. cuja & 0 & 0.007 & 0.200 & 0.800 & 1.000 \\
\hline
\end{tabular}


bioRxiv preprint doi: https://doi.org/10.1101/2020.03.04.976415. this version posted March 5,2020 . The copyright holder for this preprint (which was not certified by peer review) is the author/funder, who has granted bioRxiv a license to display the preprint in perpetuity. It is made available under aCC-BY-NC-ND 4.0 International license.

555 Table 3. Occupancy models within 2 Akaike's Information Criterion corrected for small sample size (AICc) units of top models, which show the strongest relationship between species occurrence and measured covariates in a coastal area of Buenos Aires, Argentina; p: detection parameter, $\psi$ : occupancy parameter, K: number ofparameters in the model; MacKenzie-Bailey goodness-of-fit parameters are included for the top model of each species, and include $\mathrm{X}^{2}, P$ value, and $\hat{c}$ as the overdispersion parameter. TG: tall grassland, LG: low grassland, BG: bare ground, J: Juncus spp., C: Cortaderia spp., H: Hyalis argentea, D: distancie to shoreline, S: shrubs, RAI_LGy: relative abundance index of Lycalopex gymnocercus, RAI_LGe: relative

564 abundance index of Leopardus geoffroyi.

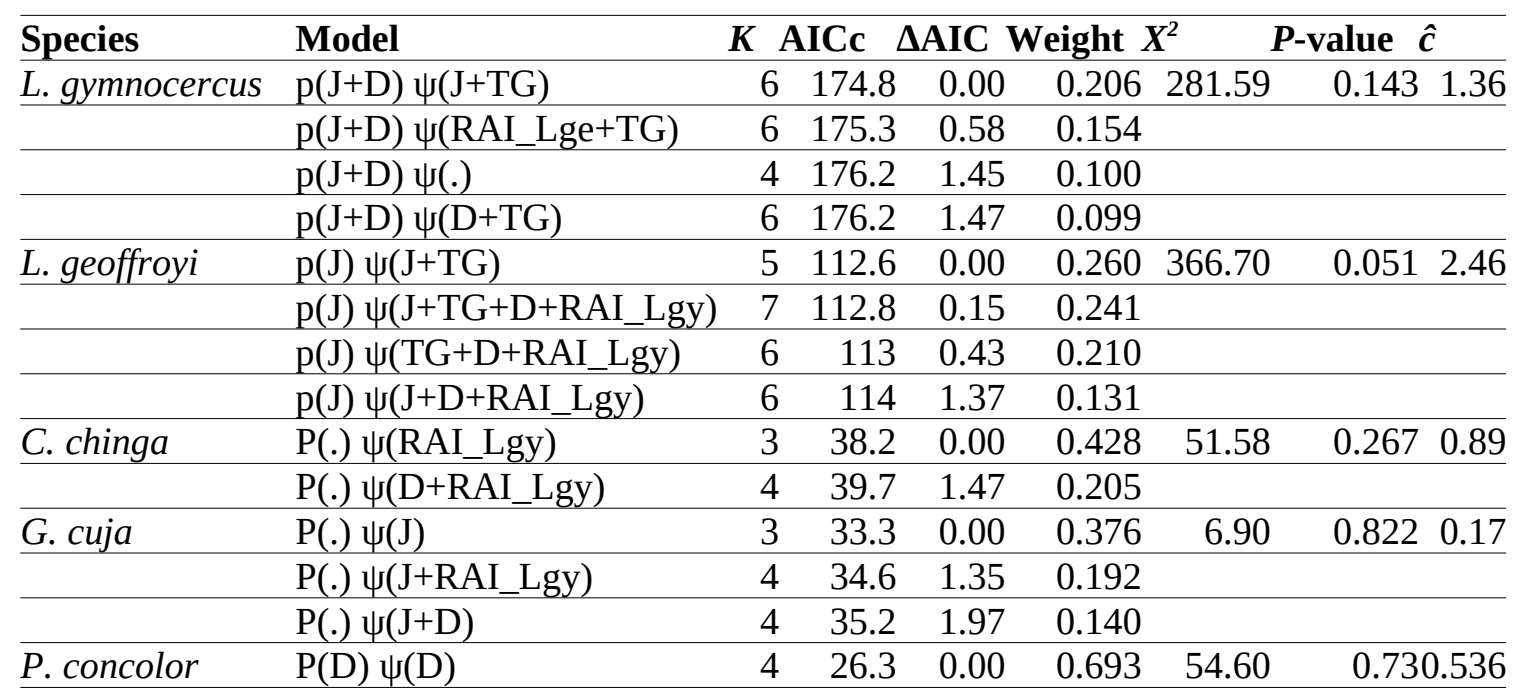


571 Figure 1. Map of the study area. Black dot in the bigger map shows the relative location of the study 572 area in Argentina. Red symbols in the inner image represent the camera trap sites.

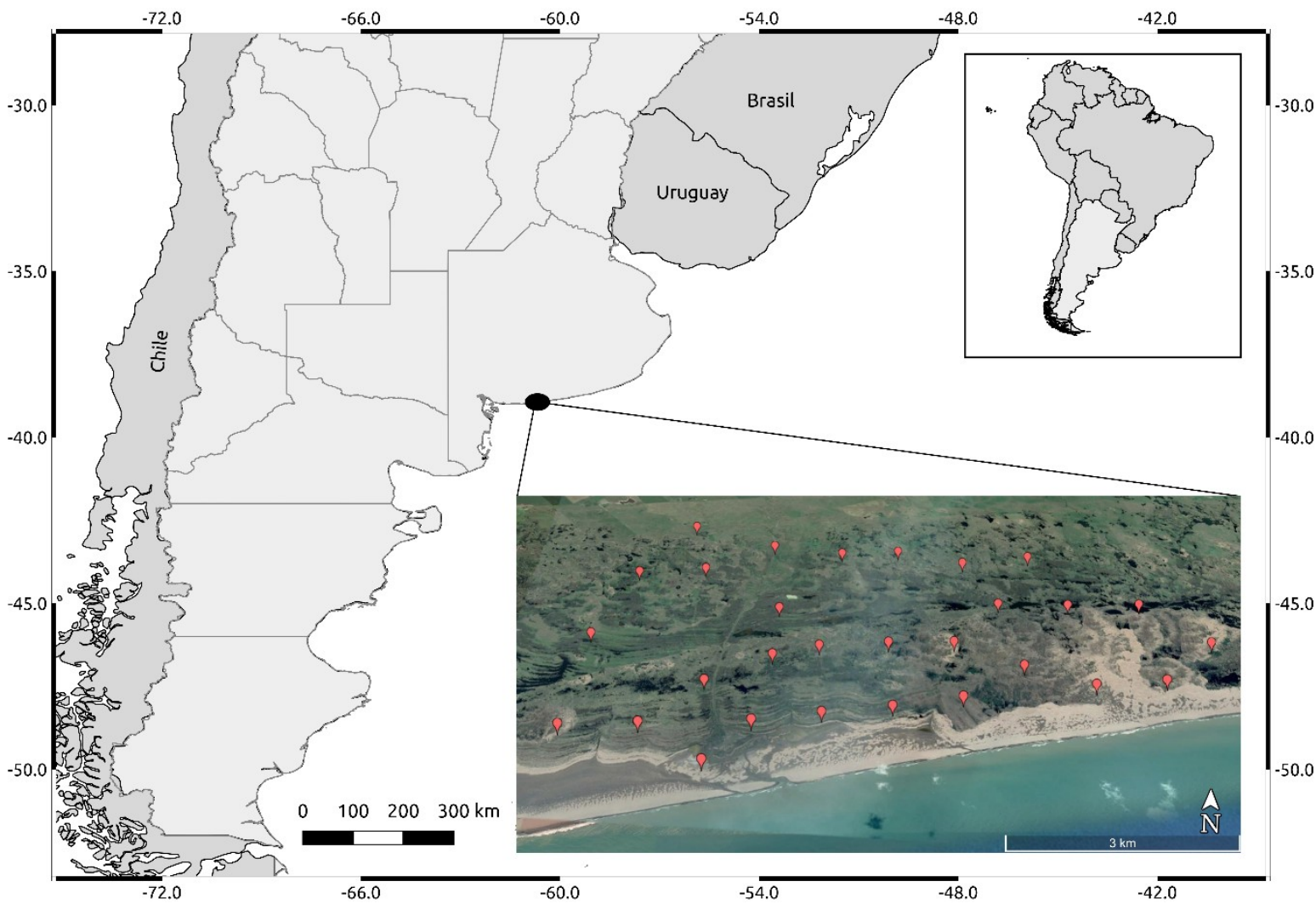


596 Figure 2. Result of Non-Metric Multi-dimensional Scaling for the carnivore species found in a 597 coastal area of Buenos Aires province (Argentina) and the post hoc environmental vectors fitting to 598 ordination (Stress $=0.028$ ). Vectors show the direction of linear correlation of the environmental 599 variables with ordination scores. TG: tall grassland, LG: low grassland, BG: bare ground, J: Juncus 600 spp., C: Cortaderia spp., H: Hyalis argentea, D: distancie to shoreline, S: shrubs, LGe: Leopardus 601 geoffroyi, LGy: Lycalopex gymnocercus, CC: Conepatus chinga, PC: Puma concolor, GC: Galictis 602 cuja.

603

604

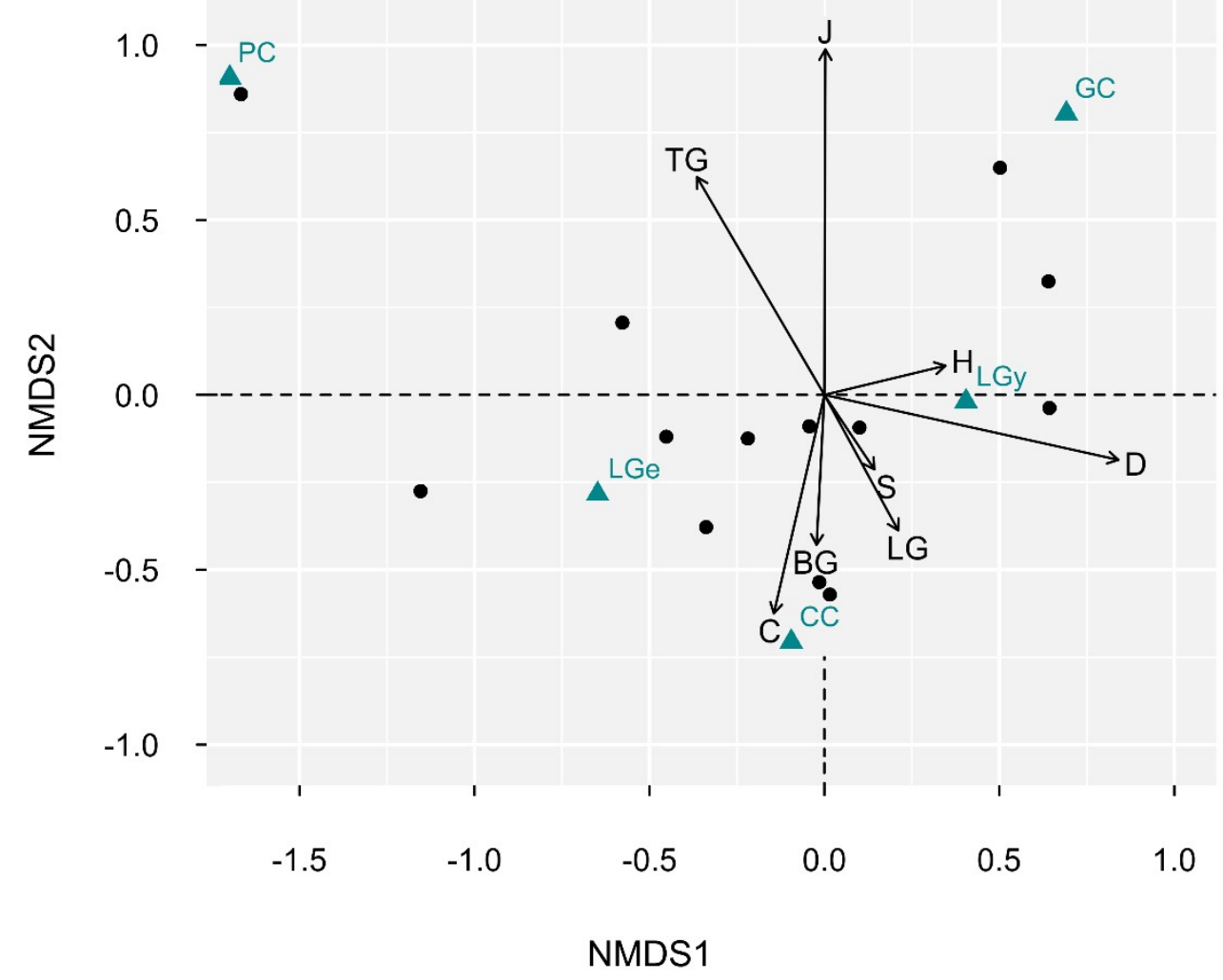


605 Figure 3. Activity patterns of carnivore species in a coastal area of Buenos Aires province, 606 Argentina: a) Lycalopex gymnocercus, b) Leopardus geoffroyi, c) Conepatus chinga, d) Galictis 607 cuja, e) Puma concolor; and f) pairwise comparison of daily activity patterns between Lycalopex 608 gymnocercus and Leopardus geoffroyi. $\Delta_{1}$ : overlap coefficient; CI: confidence interval.

609

610

611

612

613

614

615

616

617

618

619

620

621

622

623

624

625

626

627

628

629

630

631

632

633

634

635

636

637

638

a
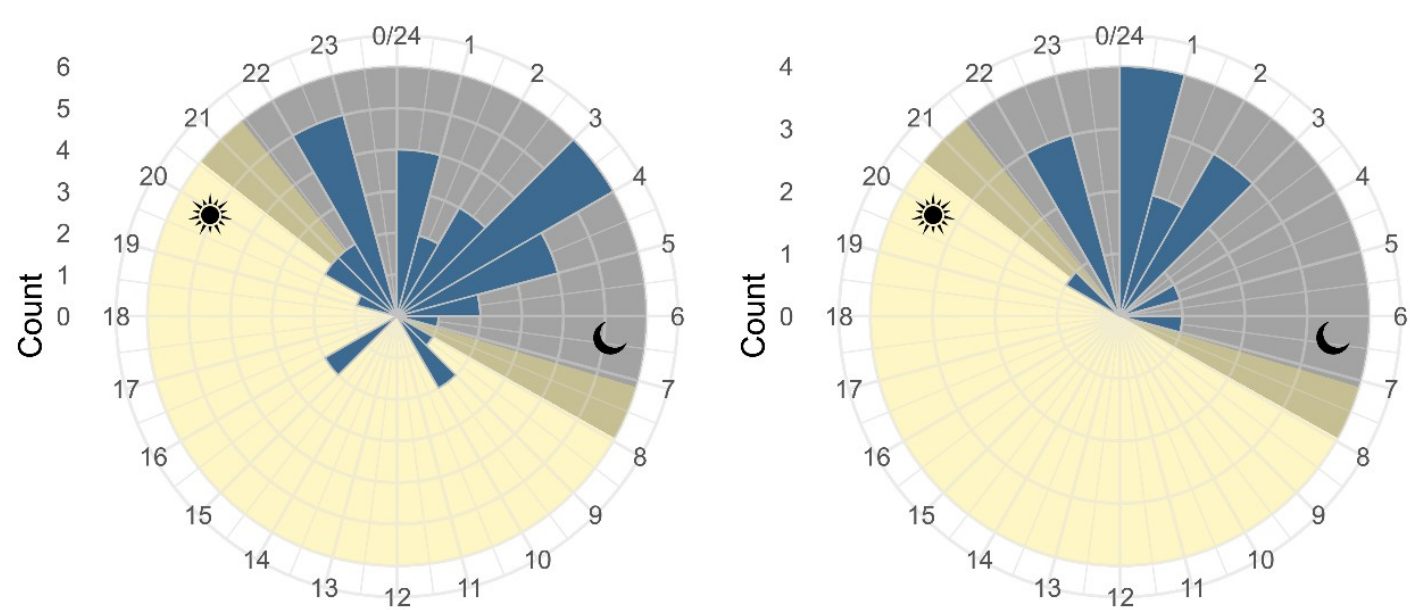

639

640

641

642

643

644

645

646

647

648

649

650

651
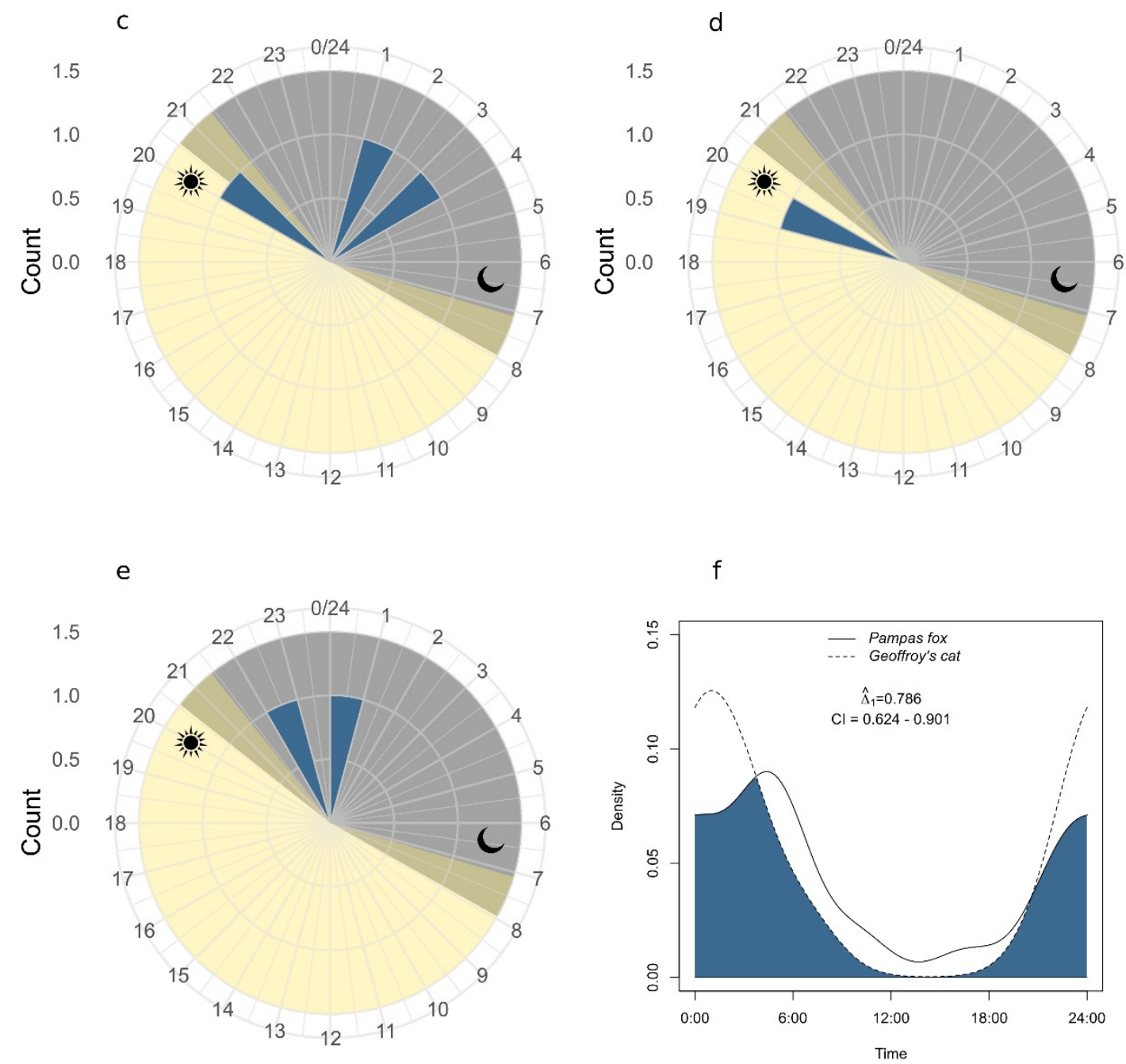